\title{
KOLABORASI PENANGANAN STUNTING
}

\section{Heni Nurhaeni, Suryati Badrin, Dinarti, Made Riasmini dan Eska Riyanti}

Politeknik Kesehatan Jakarta I, Politeknik Kesehatan III Jakarta, Indonesia

Email: hnurhaeni@gmail.com, suryati_suripto@yahoo.com,din_rh@yahoo.co.id, maderiasmini @yahoo.co.id dan ahmaddazim68@yahoo.co.id

\begin{tabular}{l}
\hline ARTIKEL INFO \\
\hline Tanggal diterima: 5 Mei 2021 \\
Tanggal revisi: 15 Mei 2021 \\
Tanggal yang disetujui: 25 Mei \\
2021
\end{tabular}

Keywords:

stunting; collaboration;

pandemic; cadre

\begin{abstract}
Stunting is a very poor health condition for a child and his family. Stunting has a big impact on the health status in the future, there are even predictions of economic decline due to stunting conditions. In the midst of the pandemic, the challenges of paradigm change, reformulation of service systems, and modification of innovations are aimed at ensuring excellent health services, in accordance with the principles of the health code of ethics. Quantitative research with quasi-experimental and literature studies with the aim of knowing the effect of strengthening maternal care knowledge on children with stunting in the pandemic. This study is a collaborative study between nurses, doctors, and health cadres that provides stunting cognition strengthening services to 28 cases of stunting during the 2019-2020 pandemic. The results showed an increase in weight in children with significant stunting as well as maternal knowledge. Strengthening collaboration is carried out in an integrated and significant, which is excellent for communication, role, and cooperation. And, the presence factor for mothers, and children who are always at home during a pandemic, intensive supervision by health cadres is an easy access factor to provide integrated reinforcement.
\end{abstract}

\section{ABSTRAK}

Stunting merupakan kondisi kesehatan yang sangat buruk bagi seorang anak dan keluarganya. Stunting berdampak besar pada status kesehatan di masa depan, bahkan ada prediksi penurunan ekonomi akibat kondisi stunting. Di tengah pandemi, tantangan perubahan paradigma, reformulasi sistem pelayanan, dan modifikasi inovasi ditujukan untuk memastikan pelayanan kesehatan yang prima, sesuai dengan prinsip kode etik kesehatan. Penelitian kuantitatif dengan kuasi eksperimental dan studi literatur dengan tujuan mengetahui pengaruh penguatan pengetahuan perawatan Ibu terhadap anak dengan stunting di masa pandemi. Penelitian ini merupakan studi kolaboratif antara perawat, dokter, dan kader kesehatan yang memberikan layanan penguatan kognisi stunting terhadap 28 kasus stunting selama pandemi 20192020. Hasil penelitian menunjukkan peningkatan berat badan pada anak dengan stunting serta pengetahuan ibu yang signifikan. Penguatan kolaborasi dilakukan secara terintegrasi 
dan signifikan, yang sangat baik untuk komunikasi, peran, dan kerjasama. Dan, faktor keberadaan bagi Ibu, dan anak yang selalu berada di rumah saat terjadi pandemi, pengawasan intensif oleh kader kesehatan merupakan faktor akses yang mudah untuk memberikan penguatan yang terintegrasi.

\section{Pendahuluan}

Stunting adalah kondisi ketika balita memiliki tinggi badan dibawah rata-rata. Hal ini diakibatkan asupan gizi yang diberikan, dalam waktu yang panjang, tidak sesuai dengan kebutuhan (Kementrian RI, 2018) Stunting berpotensi memperlambat perkembangan otak, dengan dampak jangka panjang berupa keterbelakangan mental, rendahnya kemampuan belajar, dan risiko serangan penyakit kronis seperti diabetes, hipertensi, hingga obesitas. Dan salah satu penyebab yang menjadi penyebab konsumsi kurang dari yang dibutuhkan adalah kemiskinan dan pengetahuan Ibu. (Kementrian RI, 2018) .

Menurut data WHO dalam P2PTM Kemenkes RI (2018) angka stunting Indonesia menurun, dari 29 persen pada 2015 menjadi 27.6 persen tahun lalu. Adapun pada 2013, angka stunting nasional mencapai 37,2 persen. Namun, angka tersebut masih di atas batas yang ditetapkan Organisasi Kesehatan Dunia (WHO), yaitu 20 persen. Persentase stunting Indonesia juga lebih tinggi dibanding sejumlah negara Asia Tenggara seperti Vietnam (23), Filipina (20), Malaysia (17), dan Thailand (16). Di Indonesia memiliki 5 daerah yang memiliki kemiskinan dibawah nasional. Daerah tersebut adalah Sulawesi Selatan, Kalimantan Barat, Kalimantan Tengah, Kalimantan Utara, dan Kalimantan Selatan. Selebihnya, 9 provinsi, memiliki tingkat kemiskinan tinggi.

Dengan demikian penangananan stunting terlebih saat masa pandemic, bukan saja hanya dari petugas kesehatan, selain kemiskinan, tingkat pendidikan juga berkaitan dengan permasalahan gizi. Minimnya pengetahuan membuat pemberian asupan gizi tidak sesuai kebutuhan. Contohnya adalah kurangnya kesadaran akan pentingnya inisiasi menyusui dini (IMD). Padahal IMD menjadi langkah penting dalam memberikan gizi terbaik.

Kolaborasi pelayanan sudah lama digaungkan di seluruh dunia dalam setiap kegiatan mulai dari belajar hingga profesionalisme. Petugas kesehatan senantiasa didorong untuk memberikan layanan terintegrasi melalui interprofessional kolaborasi (IPC) di masyarakat (Leathard, 2003). Saat terjadi pandemi, kolaborasi perlu diperhatikan terutama dalam upaya peningkatan pengetahuan, sikap dan keterampilan ibu dalam merawat anak stunting. Sikap peduli terhadap pemenuhan nutrisi kesehatan anak sangat penting karena dapat mempengaruhi ibu secara mendalam menjaga kondisi kesehatan (imunitas tubuh). (Karyono \& Wicaksana, 2020).

Kolaborasi memiliki domain yaitu Nilai/Etika, Peran, Komunikasi, dan Kerjasama berbagai tenaga kesehatan (Prayetni et al., 2018) dan Kader Kesehatan dapat dilakukan secara terintegrasi. Penelitian ini penting dilakukan dengan mempertimbangkan dampak stunting yang akan sangat mempengaruhi produktivitas masa depan, serta mengukur kemampuan ibu dalam mengasuh anaknya sebagai generasi penerus (Kemenkes, 2018) termasuk sebagai tolak ukur keberhasilan kerjasama. Hal itu tidak hanya dilakukan oleh sesama tenaga kesehatan, tetapi dengan kader kesehatan yang senantiasa berada dalam lingkungan keluarga dengan anak stunting. Apalagi ketika terjadi pandemi (Djalante et al., 2020), 
kita masing-masing tenaga kesehatan harus mampu berinovasi dalam memberikan pelayanan kepada masyarakat, terlebih ketika kita menghadapi kasus stunting di masyarakat yang sangat kompleks, penyebabnya antara lain melibatkan ibu-ibu, keluarga, termasuk Kader Kesehatan di lingkungan tempat dia tinggal (Wahyuningsih, 2018) .

Selaras dengan penelitian ini, (Charlotte E. Warren, et.al. 2021) dalam menemukan selama observasi sejak 2010 sampai 2016 pada pelaksanaan pelayanan kesehatan utama terdapat 3 tahap dari siklus reformasi, pengumpulan solusi, desain, dan kesiapan, mencerminkan situasi di masyarakat, bahwa dibutuhkan reformasi proporsi pelayanan harus dipertimbangkan sebagai proses adaptif dan evolusioner yang berkelanjutan; pembelajaran, tata kelola, dan sistem manajemen harus dirancang dengan mengingat model yang tersedia dalam sistem kesehatan tertentu dan yang selaras dengan sumber daya, kemampuan, dan komitmen pemangku kepentingan utama di masyarakat. Oleh karenanya pada penelitian ini memiliki kebaruan pada keterlibatan Kader Kesehatan sebagai agen pembaharu yang senantiasa berada di lingkungan tempat tinggal anakanak stunting yang dipantau di pandemi selama 2019-2020.

Penelitian ini bertujuan mengetahui pengaruh penerapan model IPC terhadap peningkatan kemampuan perilaku ibu merawat anak dengan Stunting pada bulan Mei sampai dengan September 2019, termasuk peran Kader Kesehatan aktif dalam berkontribusi melaksanakan pelayanan kepada anak dengan stunting serta monitor selama masa pandemic.

\section{Metode Penelitian}

Desain penelitian kuantitatif menggunakan one group pre-test dan posttest. Penelitian ini menggunakan metode eksperimen semu, kegiatan penelitian dimulai dengan pelatihan kolaborasi antar tim yaitu;
Perawat, Dokter, dan Kader Kesehatan (Kjell Erik Rudestam \& Newton, 2015) Selama intervensi, terutama saat pandemi, yang memberlakukan isolasi/karantina di rumah, dibantu oleh Kader Kesehatan di masingmasing wilayah yang memiliki ibu yang mengasuh anak Stunting. Jumlah responden yang menjadi sample adalah 28 orang.

\section{Hasil dan Pembahasan}

\section{A. Hasil Penelitian}

Pada analisa univariat penelitian ini akan dijelaskan karakteristik responden secara deskriptif. Berikut analisis univariat tersebut:

1. Karakteristik Responden

a. Distribusi Karakteristik responden penelitian $\quad(\mathrm{n}=28) \quad$ ditemui berpendidikan SMA: $71,4 \%$ pada kelompok intervensi dan $56 \%$ pada kelompok kontrol, memiliki satu anak dalam satu keluarga, dengan sebagian besar berjumlah 4 (empat) anggota keluarga.

b. Analisis kesetaraan jenis kelamin, status pekerjaan, status ekonomi, status perkawinan, tingkat pendidikan dan riwayat penyakit lainnya antar kelompok, ditemui: Pendidikan antara kelompok pvalue 0,027 jumlah anak 0,690 dan jumlah anggota keluarga 0,002

c. Analisis kesetaraan usia ibu dan usia anak antar kelompok ditemui Usia Ibu di kelompok intervensi dan kontrol p-value 0,055 Sedangkan usia anak ditenui p-value 0,210

d. Perbedaan skor pengetahuan dan perilaku dalam merawat anak dengan stunting antar kelompok. Pada Kelompok intervensi skor pengetahuan 0,0001 demikian pula dengan skor perilaku 0,0001. Sedangkan pada kelompok control ditemui skor pengetahuan 0,019 dan skor perilaku 0,115 . 
e. Pengaruh karakteristik responden terhadap tingkat Pengetahuan, perilaku dan tingkat kepuasan layanan tim Kolaborasi dalam merawat anak stunting ditemui pada kelompok intervensi adalah 0,0001 dan kelompok kontrol ditemui 0,200 .

\section{B. Pembahasan}

Dari hasil temuan di atas, peneliti dapat menganalisa, bahwa sebagian besar responden pada kelompok intervensi adalah ibu balita usia 33.79 tahun memiliki balita usia 25.79 bulan, berpendidikan SMA, memiliki 1 orang anak, jumlah anggota keluarga 4 orang, pendapatan keluarga sebulan sebesar $>2$ juta, memberi ASI eksklusif pada balita dan tanpa riwayat penyakit kroni atau akut. Sedangkan pada kelompok kontrol dapat disimpulkan bahwa sebagian besar responden adalah ibu balita usia 30.54 tahun memiliki balita usia 30.50 bulan, berpendidikan SMA, memiliki 1 orang anak, jumlah anggota keluarga 3 orang, pendapatan keluarga sebulan sebesar $>2$ juta, memberi ASI eksklusif pada balita dan tanpa riwayat penyakit kronis atau akut.

Hasil analisis menunjukkan ada perbedaan pendidikan, jumlah anggota keluarga, riwayat pemberian ASI eksklusif, dan riwayat penyakit kronis pada ibu antara kelompok intervensi dan kelompok kontrol. Dan dari hasil tersebut sesuai dengan (Siti Kholifah dan Wahyu Widagdo, 2016) yang memaparkan bahwa seorang Ibu akan memiliki anak sehat, bila salah satu indikatornya adalah memberikan anaknya dengan ASI.

Terdapat perbedaan usia ibu antara kelompok intervensi dan kelompok kontrol, namun terdapat perbedaan usia anak antar kelompok intervensi dan kontrol. Hasil analisis menunjukkan terdapat perbedaan bermakna skor pengetahuan, perilaku dan tingkat kepuasan layanan tim IPC dalam merawat anak dengan stunting pada kelompok intervensi sebelum dan sesudah intervensi penerapan model IPC (nilai $\mathrm{p}=0,000$ ), dan selisih nilai rata-rata peningkatan skor pengetahuan pada kelompok intervensi lebih besar (nilai selisih $=1.678$ ) sedangkan pada kelompok control ratarata selisih skor sebesar 0.535 , dan selisih nilai rata-rata skor perilaku dalam merawat anak stunting pada kelompok intervensi lebih besar (nilai selisih $=2.821$ ) sedangkan pada kelompok kontrol ratarata selisih sebesar 0714, begitupun selisih nilai rata-rata skor tingkat kepuasan layanan tim IPC pada kelompok intervensi lebih besar (nilai selisih $=1.346$ ) sedangkan pada kelompok kontrol ratarata selisih sebesar 0.285.

Hasil analisis menunjukkan bahwa terdapat perbedaan skor pengetahuan, perilaku dan tingkat kepuasan layanan tim Kolaborasi $(\mathrm{p}=0.012 ; \mathrm{p}=0.054 ; \mathrm{p}=$ 0.010) antara kelompok intervensi dan kelompok control setelah dilakukan intervensi penerapan Kolaborasi, yaitu. Komunikasi, Kerjasama, dan Peran.

Berdasarkan hasil uji multivariat ditemukan bahwa usia ibu dan riwayat pemberian ASI eksklusif berpengaruh terhadap pengetahuan akan nutrisi dalam merawat balita stunting

\section{Kesimpulan}

Selama penelitian ditemukan peningkatan berat badan anak dengan stunting sebesar $14,3 \%$, pengetahuan Ibu meningkat sampai dengan $>65 \%$, dengan kepuasan layanan IPC denagn 95\% CI $(0,395-1,853)$

nilai $F$ 7,674 dan p-value 0,010

Derajat kesehatan dipengaruhi oleh beberapa faktor, (Kemenkes.RI, 2016) yaitu keturunan, pelayanan kesehatan, perilaku dan lingkungan (Munir, 2016) memaparkan, bahwa faktor perilaku dan lingkungan 
mempunyai andil paling besar dalam meningkatkan derajat kesehatan masyarakat.

Dengan demikian dapat disimpulkan bahwa penanganan kolaborasi amat berpengaruh terhadap anak dengan stunting yang dilaksanakan selama pandemi dalam penelitian ini.

\section{BIBLIOGRAFI}

Charlotte E. Warren; Ben Bellows; Rachel Marcus; Jordan Downey; Sarah Kennedy; Nazo Kureshy. (2021). Communities As The Cornerstone Of Primary Health Care: Learning, Policy, And Practice. In Global Health And Science (Vol. 9, Issue 1). Google Scholar

Djalante, R., Lassa, J., Setiamarga, D., Sudjatma, A., Indrawan, M., Haryanto, B., Mahfud, C., Sinapoy, M. S., Djalante, S., \& Rafliana, I. (2020). Review And Analysis Of Current Responses To Covid-19 In Indonesia: Period Of January To March 2020. Progress In Disaster Science, 6, 100091. Google Scholar

Karyono, D. R., \& Wicaksana, A. L. (2020). Current Prevalence, Characteristics, And Comorbidities Of Patients With Covid19 In Indonesia. Journal Of Community Empowerment For Health, 3(2), 77. Google Scholar

Kemenkes.Ri. (2016). Program Indonesia Sehat Dengan Pendekatan Keluarga. In Kementerian Kesehatan Ri. Kementerian Kesehatan Ri. Google Scholar

Kemenkes, R. I. (2018). Hasil Utama Riskesdas 2018. In Online) Http://Www. Depkes. Go. Id/Resources/Download/InfoTerkini/Materi_Rakorpop_2018/Hasil\% 20riskesdas (Vol. 202018). Google Scholar

Kementrian Ri. (2018). Penanganan Stunting
Terpadu Tahun 2018. 11-23. Google Scholar

Kjell Erik Rudestam, \& Newton, F. R. R. (2015). Surviving Your Dissertation. In Sage Publications, Inc.: Vol. №3 (4th Ed.). Sage. Google Scholar

Leathard, A. (2003). Models For Interprofessional Collaboration. Interprofessional Collaboration: From Policy To Practice In Health And Social Care, 93-117. Google Scholar

Munir, M. (2016). Community Empowerment Aware Of Health Model. Jurnal Ners, 11(2), 288. Google Scholar

Prayetni, P., Riasmini, N. M., Palestin, B., \& Prabowo, T. (2018). Efektivitas Model Praktik Kolaborasi Interprofesional (Pkip) Tenaga Kesehatan Terhadap Kinerja Pelayanan Kesehatan Rumah. Jkep, 3(1), 24-37. Google Scholar

Siti Kholifah Dan Wahyu Widagdo. (2016). Keperawatan Keluarga Dan Komunitas. Bppsdm Kemenkes Ri. Google Scholar

Wahyuningsih, C. D. (2018). Kenormalan Baru Dan Perubahan Sosial Dalam Perspektif Sosiologi. Majalah Ilmiah Fisip Untag Semarang, 13(18), 40-60. Google Scholar 


\section{Copyright holder :}

Heni Nurhaeni, Suryati Badrin, Dinarti, Made Riasmini dan Eska Riyanti (2021)

\section{First publication right :}

Jurnal Health Sains

\section{This article is licensed under:}

(c) (i) (2) 